\title{
Deforestation forecasts in the Legal Amazon using intervention models
}

\author{
Previsões de desmatamento na Amazônia Legal usando modelos de intervenção \\ Prevenciones de deforestación en la Amazonía Legal utilizando modelos de intervención
}

Received: 03/11/2021 | Reviewed: 03/18/2021 | Accept: 03/24/2021 | Published: 04/01/2021

\author{
Anderson da Silva Costa \\ ORCID: https://orcid.org/0000-0002-3955-1817 \\ Amazônia Legal-BIONORTE, Brasil \\ E-mail: anderson.costa@embrapa.br \\ Joaquim Carlos Barbosa Queiroz \\ ORCID: https://orcid.org/0000-0002-4459-6956 \\ Universidade Federal do Pará, Brasil \\ E-mail: joaquimqz@gmail.com \\ Larissa Steiner Chermont \\ ORCID: https://orcid.org/0000-0001-9304-2418 \\ Universidade Federal do Pará, Brasil \\ E-mail: larissa@ufpa.br \\ Osmar Alves Lameira \\ ORCID: https://orcid.org/0000-0001-8370-8562 \\ Embrapa Amazônia Oriental, Brasil \\ E-mail: osmar.lameira@embrapa.br \\ Everaldo Barreiros de Souza \\ ORCID: https://orcid.org/0000-0001-6045-0984 \\ Universidade Federal do Pará, Brasil \\ E-mail: everaldo@ufpa.br \\ Marcelo Bentes Diniz \\ ORCID: https://orcid.org/0000-0001-7484-9451 \\ Universidade Federal do Pará, Brasil \\ E-mail: mbdiniz2007@gmail.com \\ Helyelson Paredes Moura \\ ORCID: https://orcid.org/0000-0001-8639-1687 \\ Universidade Federal do Amapá, Brasil \\ E-mail: helyelson@unifap.br \\ Débora Lisboa Correa Costa \\ ORCID: https://orcid.org/0000-0002-9541-5465 \\ Universidade Federal do Pará, Brasil \\ E-mail: debylisboa2007@yahoo.com.br
}

\begin{abstract}
In this paper, it was used the Box-Jenkins methodology to assess the historical deforestation data generated by PRODES in the Brazilian Legal Amazon region from 1988 to 2018, in order to acquire deforestation forecasts. Considering that the model achieved an acceptable performance, forecasts were estimated for the next seven years (2019 to 2023). If there is no significant intervention in the series, deforestation rates are expected to remain ranging from 7,559.97 $\mathrm{km}^{2}$ to $7,730.88 \mathrm{~km}^{2}$, with a mean around $7,625.12 \mathrm{~km}^{2}$. In the case of an intervention, these quantities may vary from $10,429.28 \mathrm{~km}^{2}$ to $28,669.75 \mathrm{~km}^{2}$, with a mean near to $16,766.71 \mathrm{~km}^{2}$, indicating an increase of $119 \%$ on deforestation rates. In this sense, this article reinforces the need for maintenance and expansion of the environmental governance structure for the Brazilian Legal Amazon, according to what has happened in the last decade, especially based on the instruments of Command and Control related, for example, to expansion of Conservation Units, institution of the Rural Environmental Registry (CAR), inducing land regularization, improvement of the detection and monitoring system of burning and deforestation, such as PRODES and DETER, and also ostensive operations to combat illegal deforestation governmental institutions.
\end{abstract}

Keywords: Amazon; Deforestation; Time series; Intervention models; Forecasts.

\section{Resumo}

Neste trabalho foi utilizada a metodologia Box-Jenkins para avaliar os dados históricos de desmatamento gerados pelo PRODES na região da Amazônia Legal Brasileira de 1988 a 2018, a fim de obter previsões de desmatamento. Considerando que o modelo obteve um desempenho aceitável, foram estimadas as projeções para os próximos sete anos (2019 a 2023). Se não houver intervenção significativa na série, as taxas de desmatamento devem permanecer na faixa de $7.559,97 \mathrm{~km}^{2}$ a $7.730,88 \mathrm{~km}^{2}$, com média em torno de $7.625,12 \mathrm{~km}^{2}$. No caso de intervenção, essas quantidades 
podem variar de $10.429,28 \mathrm{~km}^{2}$ a $28.669,75 \mathrm{~km}^{2}$, com média próxima a $16.766,71 \mathrm{~km}^{2}$, indicando aumento de $119 \%$ nas taxas de desmatamento. Nesse sentido, este artigo reforça a necessidade de manutenção e ampliação da estrutura de governança ambiental para a Amazônia Legal Brasileira, conforme vem ocorrendo na última década, principalmente com base nos instrumentos de Comando e Controle relacionados, por exemplo, à expansão de Unidades de Conservação, instituição do Cadastro Ambiental Rural (CAR), induzindo a regularização fundiária, aprimoramento do sistema de detecção e monitoramento de queimadas e desmatamentos, como PRODES e DETER, e também operações ostensivas de combate ao desmatamento ilegal por instituições governamentais.

Palavras-chave: Amazônia; Desmatamento; Séries temporais; Modelos de intervenção; Previsões.

\section{Resumen}

En este trabajo, se utilizó la metodología Box-Jenkins para evaluar los datos históricos de deforestación generados por PRODES en la región de la Amazonía Legal Brasileña de 1988 a 2018, con el fin de obtener pronósticos de deforestación. Considerando que el modelo logró un desempeño aceptable, se estimaron proyecciones para los próximos siete años (2019 a 2023). Si no hay una intervención significativa en la serie, las tasas de deforestación deberían permanecer en el rango de 7.559,97 km2 a 7.730,88 km2, con un promedio de alrededor de 7.625,12 km2. En el caso de la intervención, estas cantidades pueden variar de $10.429,28 \mathrm{~km} 2$ a $28.669,75 \mathrm{~km} 2$, con un promedio cercano a los $16.766,71 \mathrm{~km} 2$, lo que indica un aumento del $119 \%$ en las tasas de deforestación. En este sentido, este artículo refuerza la necesidad de mantener y ampliar la estructura de gobernanza ambiental para la Amazonía Legal brasileña, como viene sucediendo en la última década, principalmente a partir de los instrumentos de Comando y Control relacionados, por ejemplo, con la expansión de Unidades de Conservación, institución del Registro Ambiental Rural (CAR), induciendo la regularización de tierras, mejorando el sistema de detección y monitoreo de incendios y deforestación, como PRODES y DETER, así como operativos ostensibles para combatir la deforestación ilegal por parte de instituciones gubernamentales.

Palabras clave: Amazonia; Deforestación; Series temporales; Modelos de intervención; Proyecciones.

\section{Introduction}

The use of remote sensing techniques applied to forest cover monitoring is increasingly common (Ustin, et al., 1999). One of the most frequently used techniques for monitoring forest cover in the Legal Amazon is the multi-temporal analysis of sensor observations (Foody, et al., 1996; Lucas, et al., 2002). This procedure allows us to evaluate the evolution of deforestation and to predict future scenarios.

Quantitative modeling is a tool used to represent reality and can be composed by a set of equations, which in a simplified way reproduces the behavior of a system. Time series modeling can aim to predict the system response to an input and its initial state Tucci (1998). For Fonseca, et al. (1985), the development of forecasting models through time series analysis describes and analyzes the past behaviors of the series, in order to understand the process as well as being capable of provide prediction of future movements. According to Bressan and Lima (2002) and Bressan (2004), forecasting techniques help to make decisions in activities that need constant planning and evaluation, as well as reducing uncertainty on the part of the links involved in a particular area of interest.

Although deforestation is a complex phenomenon, there are techniques that develop probabilistic statistical models capable of estimating future values of a variable. Among these techniques stands out the Box-Jenkins methodology Box-Jenkins (1976). This methodology represents one of the most widespread quantitative techniques used in time series and was developed by the authors in the 1970s. Box-Jenkins models start from the idea that each value of the (temporal) series can be explained by its previous values, from the use of the temporal correlation structure that is generally between the series values Werner and Ribeiro (2003). According to Abdel-aal and Al-Garni (1997), Box-Jenkins models have been widely used for modeling and forecasting in medical, environmental, financial and engineering applications.

Since a time series has data sequentially collected over time, it is expected to have time serial correlation. Box-Jenkins models, generically known as Arima (Autoregressive Moving Average Models), aim to capture the behavior of serial correlation or autocorrelation between time series values, and based on this behavior make predictions. If this correlation structure is well modeled, it will provide good predictions Werner and Ribeiro (2003). 
In many situations, external factors (shocks) may alter the behavior of time series of variables as environmental, economic, physical, and others. In addition, economic or political measures, implementation of government programs, among others, may be considered relevant facts, which may also cause significant changes (interventions) in time series data.

The Brazilian Amazon has been losing its original forest cover since the experience of an intense process of occupation that began in the 1970s Fearnside (2005, 2006). However, throughout these four decades, different economic forces, factors or agents have assumed the most leading role in the dynamics of deforestation at each moment. Thus, for example, Mahar (1976, 1989) and Fearnside (2005) argue that both the direct effects of the tax credit policy, which attracted and sustained livestock profitability, as well as its indirect effects related to the speculative market land were decisive in the dynamics of deforestation in the region until the first half of the 1980s.

In addition, other government policies in the period, related to the creation of infrastructure, in particular, the expansion of the roads network, and the colonization and Agrarian Reform programs, are also considered relevant in this process of the agricultural frontier expansion (Walker, 2000, 2003; Nepstad, et al., 2001, 2008; Andersen, et al., 2002; Pffaf, 2009: Aldrich et al. 2012; Aldrich, 2015). On the other hand, from the 1990s, other economic activities, besides the livestock, have been taking the lead in deforestation in the Amazon, led by mechanized agriculture - soybeans, which have also enjoyed lower relative costs in the Amazon, especially due to lower land values and improved transport and logistics infrastructure, which over time have been created, such as ports, cargo terminals, waterways, all largely from incentives and governmental plans (Diaz, et al. 2008; Gonçalves, 2004; Wehrmann \& Duarte, 2004; Nepstad, et al. 2008; Domingues \& Bermann, 2012; Nepstad, et al., 2014; Wwf, 2014), in a movement of spatial growth of the planted area that has been reaching all Latin America (Hecht, 2012; Wwf, 2014).

The accumulated deforestation in the region was a total of $781,000 \mathrm{~km}^{2}$ by the end of 2017 , which corresponded to about 15\% of the total area of the Legal Amazon, and its spatial coverage occupies mainly the area known in the literature as Deforestation Arc, in a territorial trajectory that extends from the north of the state of Mato Grosso to a great extent from east to west of the south of Pará, reaching a strip of land from the East part of Maranhão and North-northwest part of the state of Tocantins and the Northern parts of the state of Rondônia, Southeast bound of the state of Acre and a strip of land of the Southern part in the Amazonas state.

Nevertheless, the growth of accumulated deforestation, in the first two decades of this century, the Amazon has experienced a strong improvement of its environmental governance structure (Moura, 2016; Azevedo, et al. 2017; Diniz, Alves \& Diniz, 2018), especially designed to deal with problems related to the dynamics of land use and land occupation, as well as natural resources management, which, due to their intrinsic characteristics, make use of fire and deforestation as a tool for agricultural production use fire (burning) and deforestation.

In this paper, the Box-Jenkins methodology is applied to historical deforestation data, released by the Brazilian Amazon Forest Deforestation Monitoring Project (Prodes), which tests for variations in the predicted deforestation trajectory, considering the restrictions that governance itself imposes in its continuity. In this sense, the main contribution of this article can be summarized in the estimation of different predicted deforestation trajectories, considering the possible identified interventions.

\section{A Theoretical Interpretation of Deforestation}

\subsection{Market Failure Combination}

The territorial extension of the Amazon and its land structure formed by more than two thirds of public lands is concordant with what Pearce (1998) calls open access externalities. In addition, poor governance and enforcement capacity in compliance with current environmental and agrarian legislation make it usual for agents who have land titles in their hands, or demarcation of land, as in the case of indigenous populations, do not have their rights guaranteed, and thus may prevent its use by someone else (Kahn, 2005; Rivas, 2014). As a consequence, an inadequate definition and / or use of property rights dominates 
in the Amazon, and this situation becomes a source of market failure and land conflicts (Jaramillo, Thomas, 1997; Alston, Mueller, 2010; Diniz, 2017)

The source of market failure resulting from imprecision of property rights and their enforcement could, according to Pearce (1998), be reinforced by three other sources of market failure that would induce or enhance deforestation. The first is a consequence from the government intervention, which by creating infrastructure and direct and indirect mechanisms to sustain the profitability of local productive activity, ultimately enhances the conversion of the forest into other forms of land use.

The two other market failures: local market failure and global market failure would be due to the markets inaccuracy to reflect the costs of deforestation, while negative externalities that fall on different population groups, depending on their geographical position, inside or outside the area directly affected by deforestation. Indeed, it can be considered externalities that fall directly on the local population and externalities that fall beyond the localities, the population residing outside the region borders related to the loss of benefits from ecosystem services destroyed by deforestation. In practice market failures occur in a divergent situation between benefits and private costs and benefits and social costs, being their exploitation process continuous and cumulative, with an overuse of forest resources and, generation of high environmental externalities, including opportunity costs (Diniz, Alves \& Diniz, 2018), by the main agents that cause deforestation in the region, which convert the original vegetation into different forms of land use and occupation.

Kaimowitz and Angelsen (1998) argue that there are two groups of forces or drives that promote deforestation: immediate causes and underlying causes. The former would comprise human activities themselves (land uses), related to different economic activities, which directly (physically) affect the environment and thus constitute the primary source of change in land cover. The second one would be related to the social environment, which may motivate, enhance or restrict the first group. Moreover, as Geist and Lambin (2001) suggest, one can distinguish the spatial scale under which these forces act. Thus, there are driving forces that act globally and regionally, that is, in a country or in a group of countries, but there are also those that are context-specific Scrieciu (2007).

Historically in 70th and 80th, there were three main agents that promoted deforestation, in a logic of exploitation more complementary by land use and occupation than substitute or competition between them: logging, livestock and agricultural activity, predominantly for subsistence Walker (1987). In this direction, according to these authors, logging takes on the role of initial pioneer, being, therefore, the first to make their way through the forest, but not to permanently occupy it, which is made from agricultural enterprises Castro (2005), that establish a domain of land already deforested either legally or illegally. Thus, the exploitation of wood, in this relationship dynamics, assumes a predatory character, since about two thirds of the trees exploited are not commercially used, becoming this activity selective and itinerant Alves and Homma, (2008).

More recently soy growth of the production or even other cultures as maize have created an indirect spatial in which "a change in land use in one location, which is responsible for another potentially distant", inducing the cattle to new regions of agricultural frontier in the Amazon (Arima, et al. 2011; Andrade et al., 2013; Richard, et al., 2014).

Initially more economically favorable conditions led the predominantly extensive beef cattle to take the lead in the process of occupation of the region, so it could have comparative advantages over other regions such as: tax and credit incentives; lower relative land prices; improvement of physical road infrastructure and after supply conditions; growth of local population, with consequent growth of local domestic demand for meat; good adaptation to the climatic conditions of breeds initially introduced in the region, such as zebu and mestizo cattle, as well as adequacy of the predominant forage system introduced, brachiaria, low cost and good recovery in degraded areas (Walker, et al., 2000; Margulis, 2003, Alencar, et al., 2004; Arima et al., 2006; Barreto, Pereira \& Arima., 2008; Diniz, et al. 2018).

Other more recent factors, starting in the mid-1990s, also had a positive effect on livestock growth in the region, such as the genetic improvement of cattle; the eradication of foot-and-mouth disease; and the favorable domestic and foreign economic 
environment, due to domestic economic growth, exchange rate devaluation and increased trend in commodity prices (Nepstad, et al. 2008; Walker, et al. 2009; Hecht, 2012).

The set of factors listed above contributed to make the profitability of livestock activity attractive in the region, but also, the external economic environment mainly due to the increase of commodity prices, was an important factor for the expansion movement of the agricultural frontier of the region. mechanized culture, particularly soybeans, which had originally settled in the Amazon region in the 1980s from Cerrado (similar to Savannah) areas of the state of Mato Grosso but migrated northwards to the southern and eastern borders of the Pará, Rondônia, Amazonas and western Maranhão, between 1990 and 2010.

Thus, the soy crop that had good conditions of initial adaptation and climatic adaptation to the Cerrado, now shelters in extensive regions of transition cerrado-forest, including taking advantage of degraded lands (Muller \& Bustamante, 2002; Domingues \& Bermann, 2012) and at the same time, they receive preferential treatment of government credit support policies, pricing policy and expansion and improvement of transportation and logistics infrastructure (Diaz, et al. 2008; Wehrmann; Duarte, 2004; Nepstad, et al., 2008; Domingues \& Bermann, 2012). In addition, it could also enjoy lower relative land prices in the border areas (Castro, 2005) or even were benefited by more favorable international prices movement (Ferreira \& Coelho, 2015; Faria \& Almeida, 2016).

Studies like Simmons, et al. (2010); Aldrich, et al. (2012); Aldrich (2015) and Bronw, et al. (2016) found that for diferente ways contentious land changes involving disputes between landholders, peasant, landless people and traditional people as indigenous, rubber tappers, and fisher communities have been accounts for an appreciable component of deforestation. In geral, this process generates what Aldrich et al. (2012) call "time to carry out preemptive deforestation". For Brown et al. (2016) in the case direct- action land reform landholders tend to claim to the land and/or to ensure higher compensation is paid by the government when it is eventually expropriated.

In addition, as Reydon (2011) and Reydon et all., (2020) point out, land speculation works as a driver of deforestation, because it is a factor of significant appreciation of the value of the land and consequently of the value of the property to be used for agricultural purposes, in an process that begin of "occupation forested land without clear legal rights or protection (private or public)" and ends with the development of more modern forms of agriculture.

The construction of environmental governance in the Amazon is a result of accumulated experience over the last three decades, based on six major strategies, predominantly directed by the Federal Government; i) creation and / or organization of physical institutions aimed at the protection of natural resources and their biodiversity and the protection and conservation of forests, such as the 1989 restructuring of the Brazilian environmental policy executing agencies with specific functions Brazilian Institute of the Environment; Renewable Natural Resources - Ibama and later in 2007 from the Chico Mendes Institute for Biodiversity Conservation and, in 2006, the creation of the Brazilian Forest Service, all of these bodies linked to the Ministry of the Environment; ii) adoption of programs and/or plans to combat burning and deforestation, such as the Plan of Action for Prevention and Control of Legal Amazon Deforestation - Ppcdam (2004); iii) creation of a Prodes / Deter deforestation and burning control and monitoring system, housed at the National Institute for Space Research-INPE; iv) creation of the System of Conservation Units - SNUC in 2000, which later had its initial extension expanded along with the indigenous lands, reaching in 2010 approximately 44\% of the territorial extension of the Legal Amazon; v) creation of a more punitive regulatory framework for violators, such as Federal Decree 6,321/07, which created the idea of shared responsibility among different agents forming the productive chain related to deforestation promoting activities, associating penalties in solidarity with the identified agents; vi) the creation of operations to combat illegal deforestation, such as real task forces involving environmental control agencies; Federal Police, army, which in addition to arrest the violators, burns and destroys the equipment used for the logging (Fire Arch Operation, Pirate Ox Operation, Sustainable Amazon Plan, Green Wave Operation). 
The official environmental governance created by governments in different instances is pointed in many empirical studies as one of the main determinants of deforestation decline, especially between 2004 and 2013 (Soares-Filho, et al., 2005; Soares-Filho, et al., 2010; Hecht, 2012; Walker et al., 2014; Diniz et al., 2018; Azevedo-Ramos; Moutinho, 2018), although the impact of governance at different governmental scales may have different impacts on the control of deforestation (Wehkamp, J. et al.,2018; Herrera et all., 2019).

Nevertheless locally created governance involving other social actors like soy companies, NGOs and traditional populations are important too. One example was agreements such as the TAC da Carne and the Soy Moratorium that commodity traders, such as ADM, Bunge, Cargill, and others, pledged not purchase soybeans grown on areas in the Brazilian Amazon that were cleared after July 2006 (changed to July 2008 in the 2014 renewal) (Nepstad, et al., 2014; Gibbs, et al., 2015; Rausch \& Gibbs, 2016)

An important institutional innovation implanted through the New Brazilian Forest Code (2012), was the obligation to private landowners to register in state-level land registries (CAR) owned to National Rural Environmental Registry System (SICAR). Although the preliminary CAR experiences in Pará and Mato Grosso suggest that its implementation has not contributed significantly to the observed reductions in deforestation from 2008 to 2012 (Azevedo, et al. 2017). In contrast CAR enrollment from 2006 to 2013 was able to avoid deforestation in an expressive area in Mato Grosso and Para state and CAR effectiveness seems growth over time (Alix-Garcia, Arausch, L’Roe, Gibbs, 2018).

\section{Materials and Methods}

Despite the importance of events that can change the behavior of time series, generally considered as interventions, this type of tool has been rarely used to aid in time series predictions. This type of approach has not been found in historical data in the Amazon. Examples of case studies using this methodology can be found in SAS Institute, 1996 (p. 101) and Brocklebank and Dickey, 2003 (p. 165). The data for the research were obtained directly from official sources, as INPE (2019). Deforestation data were submitted to a statistical analysis, enabling valid inferences to the context considered and replication possibilities for Pereira et al, (2009). For the interpretation and theoretical reflection of the results, several studies related to the socio-economic and environmental issue related to deforestation in the Legal Amazon were consulted.

\subsection{Study area}

The Legal Amazon was initially created as the area of operation of the Superintendence of the Amazon Economic Valorization Plan (SPVEA) in 1953. The establishment of the geopolitical definition "Legal Amazon" occurs in 1966, and currently comprises the region of nine states (Acre, Amapá, Amazonas, Maranhão, Mato Grosso, Pará, Rondônia, Roraima and Tocantins), as shown in Figure 1. It consists of 772 municipalities distributed in an area comprising 5,217,423 $\mathrm{km}^{2}$, which corresponds to $61 \%$ of the total Brazilian territory. In addition, 52 cities have borders with seven countries: Bolivia, Colombia, Guyana, French Guiana, Peru, Suriname, and Venezuela (Brazil, 2007). In this study, the state of Maranhão was analyzed by integrating all municipalities, not only the western part. The climate is equatorial, hot and humid, with the temperature varying little during the year, around $26^{\circ} \mathrm{C}$ (Almeida et al., 2010). Rainfall in the Amazon exhibits a well-defined annual cycle with maximum (rainy season) during summer and autumn and minimum (dry or less rainy period) during austral winter (Marengo, et al., 2001; Souza \& Ambrizzi, 2003), during December to May in the Eastern Amazon Figure 1. 
Figure 1. Map of the political-administrative division of the Legal Amazon.

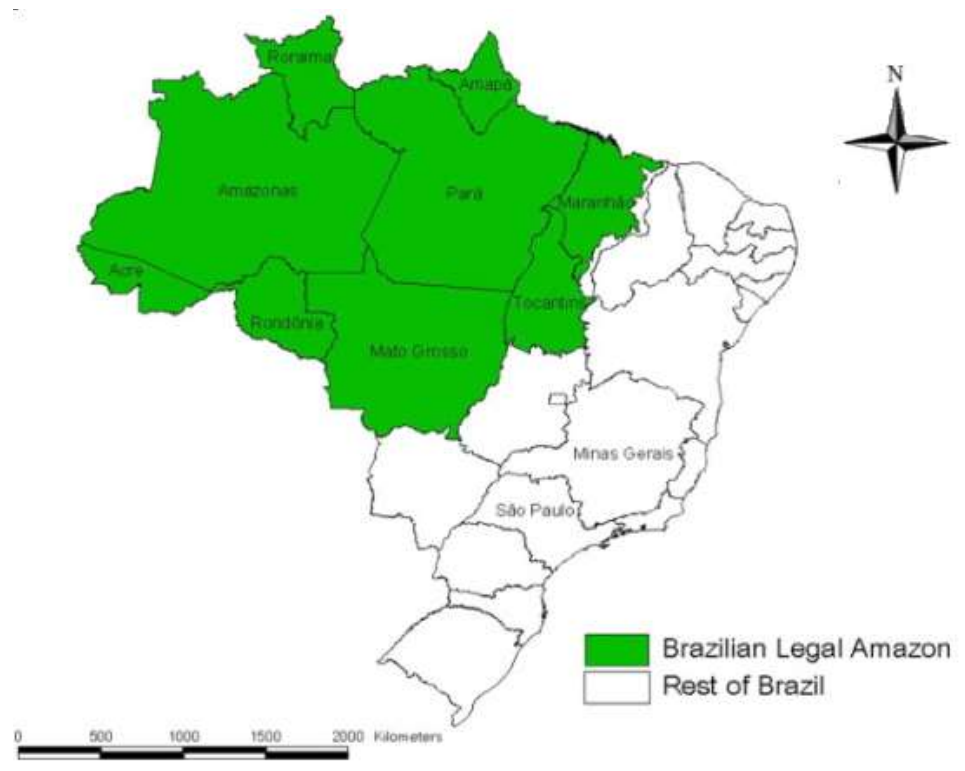

Font: Science.direct.com.

\subsection{Time Series}

For the analysis of deforestation rates and forecasting for the coming years, the Box-Jenkins time series methodology was used. A time series (TS) can be defined as a set of observations, $Y_{t}$ as a function of time (Morettin \& Toloi, 2004). The main tools used for time series analysis are: auto-correlation and partial auto-correlation functions. The auto-correlation function (ACF) represents the simple correlation between $Y_{t}$ and $Y_{t-k}$ and the lag of $k$ function. The auto correlation function of an ST $\left\{Y_{t}\right\}$ can be defined as:

$$
\rho=\frac{\sum_{t=0}^{N-k-1}\left(Y_{t}-\bar{Y}\right)\left(Y_{t+k}-\bar{Y}\right)}{\sum_{t=0}^{N-1}\left(Y_{t}-\bar{Y}\right)^{2}}
$$

Where $\mathrm{N}$ represents the length of ST and $\bar{Y}$ is the expected value of the observations, calculated for the temporal variation (lag) $\mathrm{k}$. The autocorrelation coefficient $(\rho)$ of an ST ranges from -1 to 1 inclusive. If $\rho$ assumes the value 1 , the two measured variables have an absolute positive autocorrelation, otherwise if $\rho=-1$, the negative autocorrelation is absolute. When $\rho$ assumes the value zero, there is no autocorrelation between variables, where the observations are considered independent. The partial autocorrelation function (PACF) represents the correlation between $Y_{t}$ and $Y_{t-k}$ as a function of the delaying $k$, filtered the effect of all other delays on $Y_{t}$ and $Y_{t-k}$. The partial autocorrelation function is defined as the sequence of correlations between ( $Y_{t}$ and $\left.Y_{t-1}\right)$, (Yt and Yt-2), $\left(Y_{t}\right.$ and $\left.Y_{t-3}\right)$, and so on, as long as the effects of previous delays on $t$ remain. constant. The PACF is calculated as the value of the coefficient $\varphi_{\mathrm{kk}}$ in the equation (2).

$$
Y_{t}=\phi_{k 1} Y_{t-1}+\phi_{k 2} Y_{t-2}+\phi_{k 3} Y_{t-3}+\ldots+\phi_{k k} Y_{t-k}+u_{t}
$$

Moretin and Toloi (2004), recommend that at least 48 observations should be used in order to have good estimates of self-correlating functions. Samples with less than 48 observations can generate estimates with longer confidence intervals, for instance less accurately. An Arima model can be thought of as a population regression function for $Y_{t}$ where there are only 2 types of explanatory variables: Past values $Y_{t}$ (the autoregressive part) and present and past values of the normal disturbance $u_{t}$ (the moving average part.) The general form of the equation (Box \& Jenkins, 1976) is given by

$$
Y_{t}=\phi_{1} Y_{t-1}+\ldots \phi_{p} Y_{t-p}+u_{t}-\theta_{1} u_{t-1}-\ldots-\theta_{q} u_{t-q}
$$


Where $p$ is the maximum lag of $Y_{t}$ present in the equation, $q$ is the maximum lag of $u_{t}$ present in the equation and $\phi$ and $\theta$ are the autoregressive and moving average parameters, respectively, of the model to be determined.

The Arima model class is particularly flexible. It is capable of producing, with very few parameters, time series with the most varied behaviors. In general, models are presented in the form of equations that include $B$ operators which are delay operators, $B^{k} Y_{t}=Y_{t-k}$, according to equation 4 , that is:

$$
\left(1-\phi_{1} \mathrm{~B}-\phi_{2} \mathrm{~B}^{2}-\ldots-\phi_{p} \mathrm{~B}^{\mathrm{p}}\right)(1-\mathrm{B})^{d} Y_{t}=\left(1-\theta_{l} \mathrm{~B}-\theta_{2} \mathrm{~B}^{2}-\ldots-\theta_{q} \mathrm{~B}^{q}\right) u_{t}
$$

or

$$
\phi(\mathrm{B}) \Delta^{d} Y_{t}=\theta(\mathrm{B}) u_{t}
$$

where $\Delta^{d}=(1-\mathrm{B})^{d} \Delta^{d}=(1-\mathrm{B})^{d}$ is the difference operator, used to make the series stationary.

In this study, a model based on a time series intervention analysis was elaborated in the studied period. An intervention corresponds to the occurrence of some type of event at a given instant of time $T$, known a priori. This occurrence may manifest for a subsequent period of time and that affects temporarily or permanently the series under study. According to Wei (1989), this technique aims to evaluate the impact of such an event on the behavior of the series. In this context, it was observed in the historical series under study evidence of alterations probably caused by factors that could be considered as interventions. The intervention model uses dummy variables to define the levels of occurrences (deforestation rates) before and/or after the intervention in the series and $N_{t}$ represents the observed values of the series, considered as residuals, but which should always be corrected. In other words, they will always have significant correlations, since the dummy variable alone does not explain the variations of the response variable. The parameters models can be estimated by Least Squares or Maximum Likelihood. In this case, the model parameters were estimated by Maximum Likelihood, where the likelihood function is maximized via nonlinear least squares using the Marquard's method (Ansley; Newbold, 1980). A significance level of 5\% was adopted for the model parameter estimates. A general class of models that takes into account the occurrence of multiple interventions is given by equation (5),

$$
Z_{t}=\sum v_{j}(\mathbf{B}) X_{j, t}+N_{t}
$$

Where $N_{t}$ is the time series free of the effect of interventions (called residual series), $X_{j, t}, j=1,2, \ldots k$, are intervention variables represented by dummy variables (assuming values 0 or 1). $v_{j}(\mathbf{B}), j=1,2, \ldots, k$, are rational functions (transfer function filter) of the formula $\frac{\omega_{j}(\mathbf{B}) \mathbf{B}^{b_{j}}}{\delta_{j}(\mathbf{B})}$, where $v_{j}(\mathbf{B})$ is the filter transfer function, $\omega_{0}$ is the scale factor, $\omega_{j}(\mathbf{B})=\omega_{j, 0}$ $-\omega_{j, 1}(\mathbf{B})-\omega_{j, 2} \mathbf{B}^{2}-\ldots-\omega_{j, s} \mathbf{B}^{s}$ e $\delta_{1}(\mathbf{B})=1-\delta_{j, 1}(\mathbf{B})-\delta_{j, 2} \mathbf{B}^{2}-\ldots-, \delta_{j, r} \mathbf{B}^{r}$ are polynomials in $\mathbf{B}$, delay operator defined as $\mathbf{B} Z_{t}=Z_{t-1}$ e $b_{j}$ is the time lag for the beginning of the $j$-th intervention effect.

The identification of interventions is made by comparing the behavior of $Z_{t}$ close to the intervention point through a catalog of behaviors typical of several theoretical models. In the construction of time series models, the program R3.5.1 was used. 


\section{Analysis and Discussion of Results}

For the evaluation of the forecast performance, the last 4 years of the series (2015 to 2018) were separated to be compared with forecasts of the intervention model to be adjusted. That is, the forecast results will be compared to the observed deforestation data so that the quality of the predictions made by the model can be assessed.

Initially, it can be seen in the graph of the historical series of annual deforestation rates in the Amazon, for the period from 1988 to 2018 (INPE, 2019), indications of possible external events that can be characterized as interventions (Figure 2a). It is possible to highlight two atypical situations in 1995 and 2004. In these years, there was a high and sudden increase in deforestation, and in 2004 there is a minor decrease in annual deforestation rates. Thus, two interventions in the series that occurred in these highlighted periods were considered.

Figure 2. (a) Amazon deforestation rates from 1988 to 2018, with two interventions indicated in 1995 and 2004 (dashed lines); Intervention Models: (b) Impulse; (c) Exponential impulse.
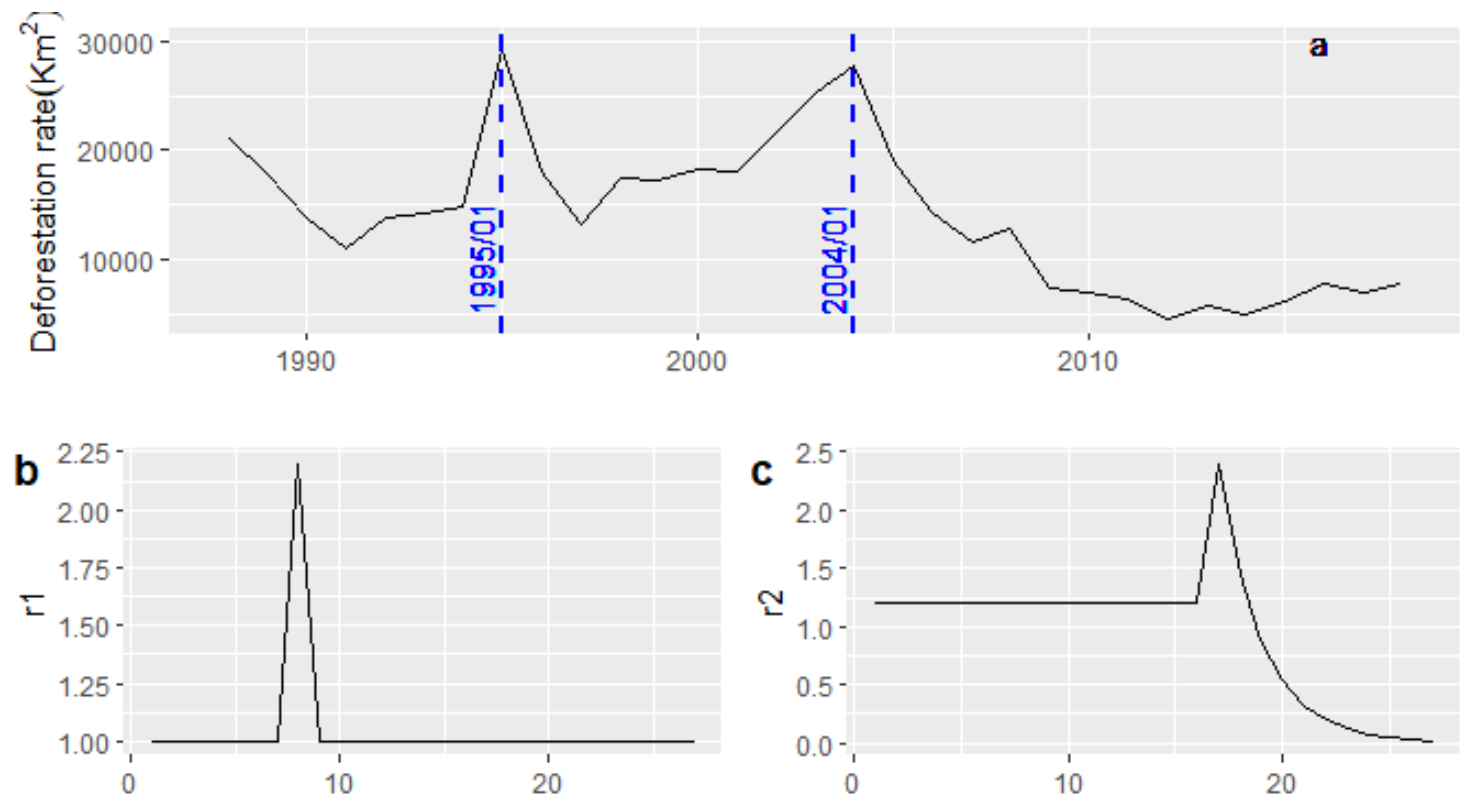

Source: Authors.

Based on the behavior of the deforestation series presented in Figure 2a, two intervention models were used to follow the behavior of the series: one of impulse type, given by equation (6) and another of impulse-exponential type, given by equation (7), shown in Figure $2 b$ and $2 c$, respectively.

$$
X_{1 t}=w_{0} t \quad \text { (6) } \quad X_{2 t}=\frac{w_{1} e^{\frac{-t}{2}}}{(1+0,001 t)}
$$

where $w_{0}$ and $w_{l}$ are the parameters of the model to be estimated and which will indicate if the interventions were significant, that is, if the behavior of the series was altered because of these external factors.

Then, using equation (5), the two intervention models given by equations (6) and (7) were adjusted to the deforestation series, whose results are presented in equation (8) and Figure 3a, represented by the continuous slim line. The parameter estimates of the intention models, $w_{0}(6658.72)$ and $w_{1}(8873,6)$ were highly significant, with descriptive levels $p<0.0001$. This indicates that the interventions considerably altered the behavior of the deforestation series in the period under study. 


$$
Z_{t}=\underset{(p<0,0001)}{6658,72 \mathrm{t}}+\frac{\underset{(p<0,0001)}{8873,6 e^{\frac{-t}{2}}}}{(1+0,001 t)}+N_{t}
$$

To make predictions, it is necessary to make the error correction, that is, to model the residual series $N_{t}$, shown in equation 8 , which showed significant correlations (Figure $3 \mathrm{~b}$ and 3c).

Figure 3. (a) Intervention Models and Intervention Model with errors adjusted to the deforestation series in the Legal Amazon; (b) Auto-correlation function of the residuals $\left(N_{t}\right)$; (c) Partial auto-correlation function of residuals $\left(N_{t}\right)$.

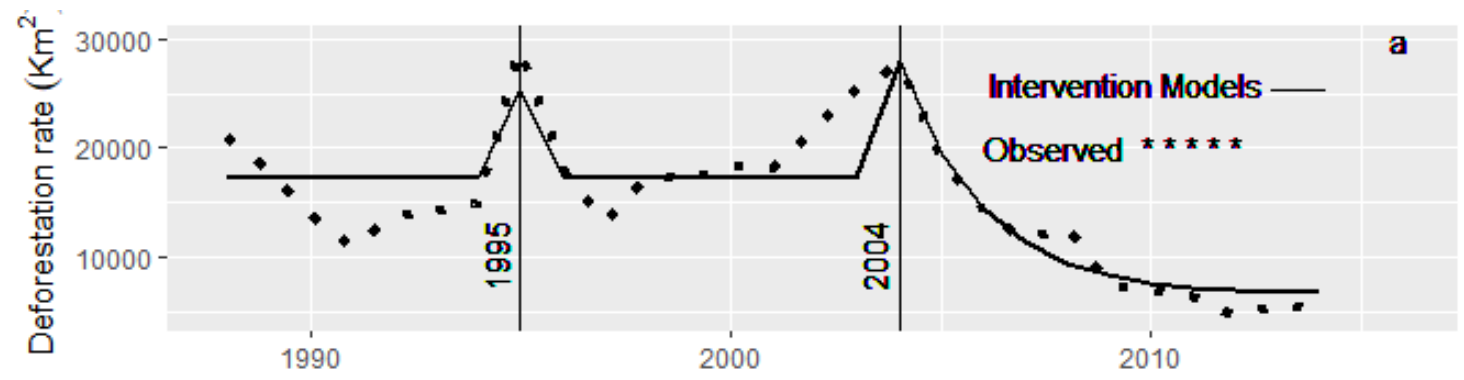

b

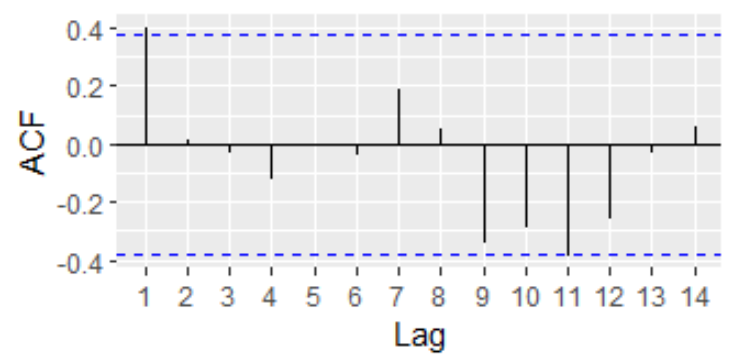

C

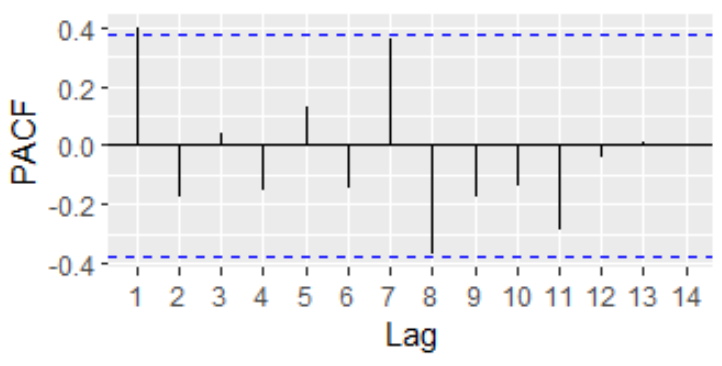

Source: Authors.

Based on the ACF and PACF analysis of the $N_{t}$ series, a model represented in equation (9) was fitted to the respective series. Estimates of the (autoregressive) parameters of the model were significant at a level of less than 5\% (significance levels are shown in parentheses in equation (9) below estimates). The quality of fit can be assessed by residual analysis of ACF and PACF. In this case, as the ACF and PACF residuals $\left(u_{t}\right)$ of the $N_{t}$ series did not present significant correlations, they can be considered as white noise, indicating that the model fit the series appropriately.

$$
(1-\underset{(p<0,0178)}{0,413 \mathrm{~B}})\left(1+\underset{(p<0,0136)}{0,447} B^{9}\right) N_{t}=u_{t}
$$

After error correction ( $N_{t}$ series), based on the equation (5), the intervention model in the equation (10) was adjusted to the deforestation series. The first and second terms of equation (10) are the intervention models and the denominator of the third term are corrected errors $\left(N_{t}\right)$. The parameter estimates of the equation model (10) are presented in equation (11), with their respective significance levels (in parentheses below the estimates) and the adjusted model (error corrected intervention model) is shown in Figure 3a, represented by the thickest continuous line. A good fit to the data can be observed (Figure 4a) as all estimates were significant at levels below 5\%. The auto-correlation and partial auto-correlation functions of the residuals $\left(e_{t}\right)$ of the equation 11 are shown in Figure $4 \mathrm{~b}$ and 4c, respectively, where the good fit of the model to the data can be confirmed due to the absence of significant correlations in them. . 


$$
\begin{gathered}
Z_{t}=X_{1 t}+X_{2 t}+\frac{e_{t}}{\left(1-\delta_{1} B\right)\left(1-\delta_{2} B^{9}\right)} \\
Z_{t}=\underbrace{8601,58}_{(p<0,0001} t+\frac{\underbrace{7031,50}_{(p<0,0001)} e^{\frac{-t}{2}}}{(1+0,001 t)}+\frac{e_{t}}{(1-\underbrace{0,5344}_{(P<0,010)} B)(1+\underbrace{0,4222}_{(P<0,033)} B^{9})}
\end{gathered}
$$

With the aid of the model (11), four deforestation forecasts were estimated for 2015 to 2018, whose values are known and, thus, can be compared to the forecasts model.

In the Table 1 are shown the results. Confidence intervals for $95 \%$ were too wide due to the small amount of data (31 observations), indicating poor accuracy. However, it is observed in Figure 4 that the estimates were close to the observed values of deforestation. The largest difference between the observed value and the forecast was observed in 2015 . A general error measure was calculated, the MAPE (Mean Absolute Percentage Error), which was in the order of $2.55 \%$.

Figure 4. (a) Intervention model adjusted to the deforestation series in the legal Amazon. b) Auto-correlation function of the residuals $\left(e_{t}\right)$; (c) Partial auto-correlation function of residuals $\left(e_{t}\right)$.
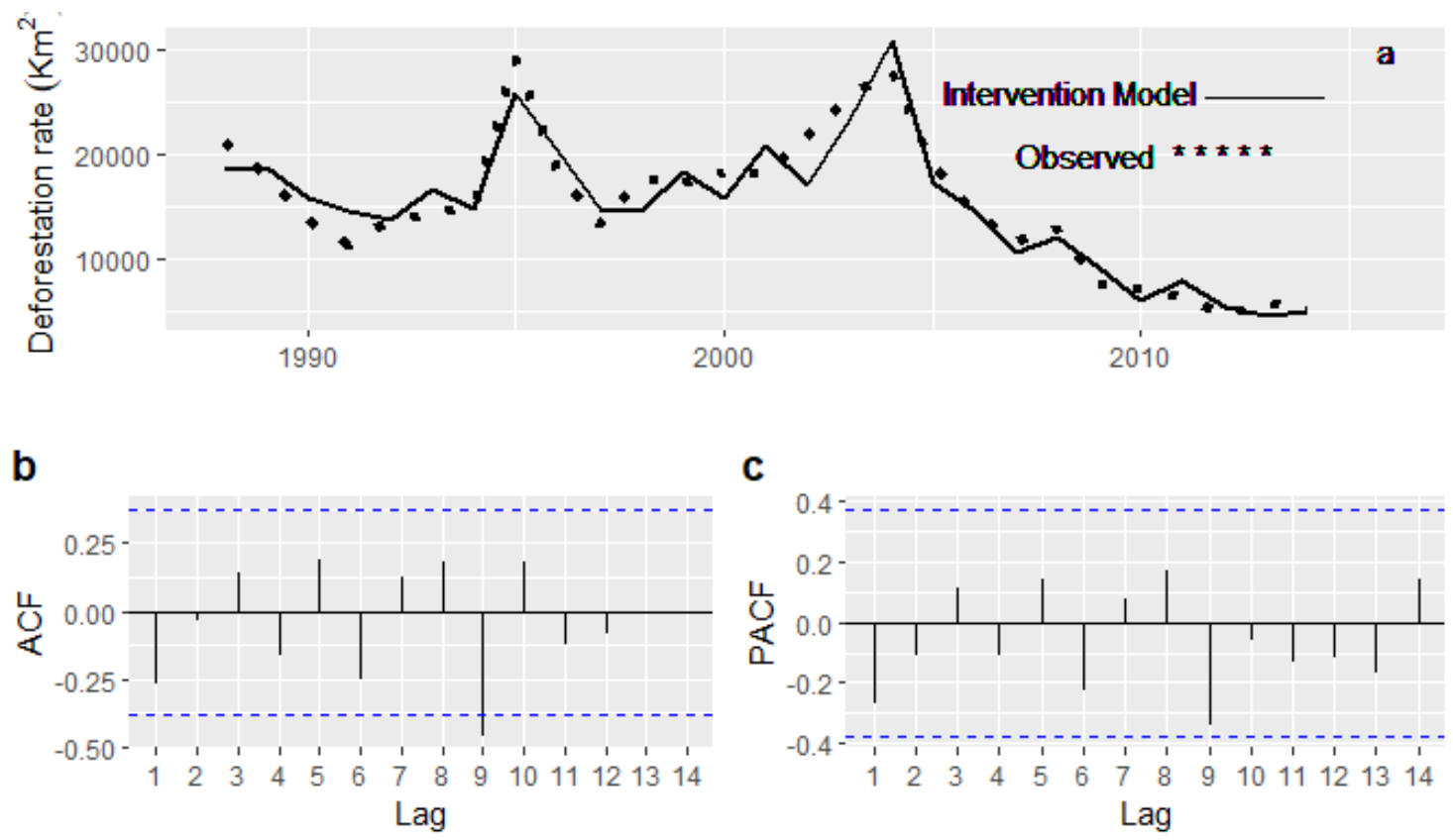

Source: Authors.

Table 1. Observed values and predictions for deforestation $\left(\mathrm{km}^{2}\right)$ in the Amazon.

\begin{tabular}{lccccr}
\hline Year & Observed & Prediction & LI $(95 \%)$ & LS $(95 \%)$ & Error \\
\hline 2015 & $6,207.00$ & $7,233.42$ & $2,586.02$ & $11,880.83$ & -1026.42 \\
2018 & $7,893.00$ & $7,452.13$ & $2,724.57$ & $12,179.70$ & 440.87 \\
2017 & $6,947.00$ & $7,417.06$ & $2,686.73$ & $12,147.39$ & -470.06 \\
2018 & $7,900.00$ & $7,760.05$ & $3,029.63$ & $12,490.48$ & 139.95 \\
\hline
\end{tabular}

LI and LS : Confidence Limits de 95\%, Inferior e Superior, respectively. Source: Authors.

Considering that the model achieved an acceptable performance, forecasts were estimated for the next years (2019 to 2025), considering a scenario of absence and another of presence of a future intervention in the series. If there is no significant 
intervention in the series, deforestation rates should be in the coming years (2019-2025) ranging from 7,559.97 $\mathrm{km}^{2}$ to $7,730.88$ $\mathrm{km}^{2}$, with an average of $7625.12 \mathrm{~km}^{2}$ and $95 \%$ confidence intervals ranging from 2829.54 to $12641.31 \mathrm{~km}^{2}$. In this sense, for this less pessimistic scenario, approximately $53375.83 \mathrm{~km}^{2}$ will be deforested by 2023. (Table 2 and Figure 5).

Figure 5. Deforestation forecasts for the years 2015 to 2018 and 2019 to 2023 in the Amazon, with Intervention (traced line) and without Intervention (dotted) with 95\% confidence intervals (gray areas) and observed data for 2015 to 2018 (solid line).

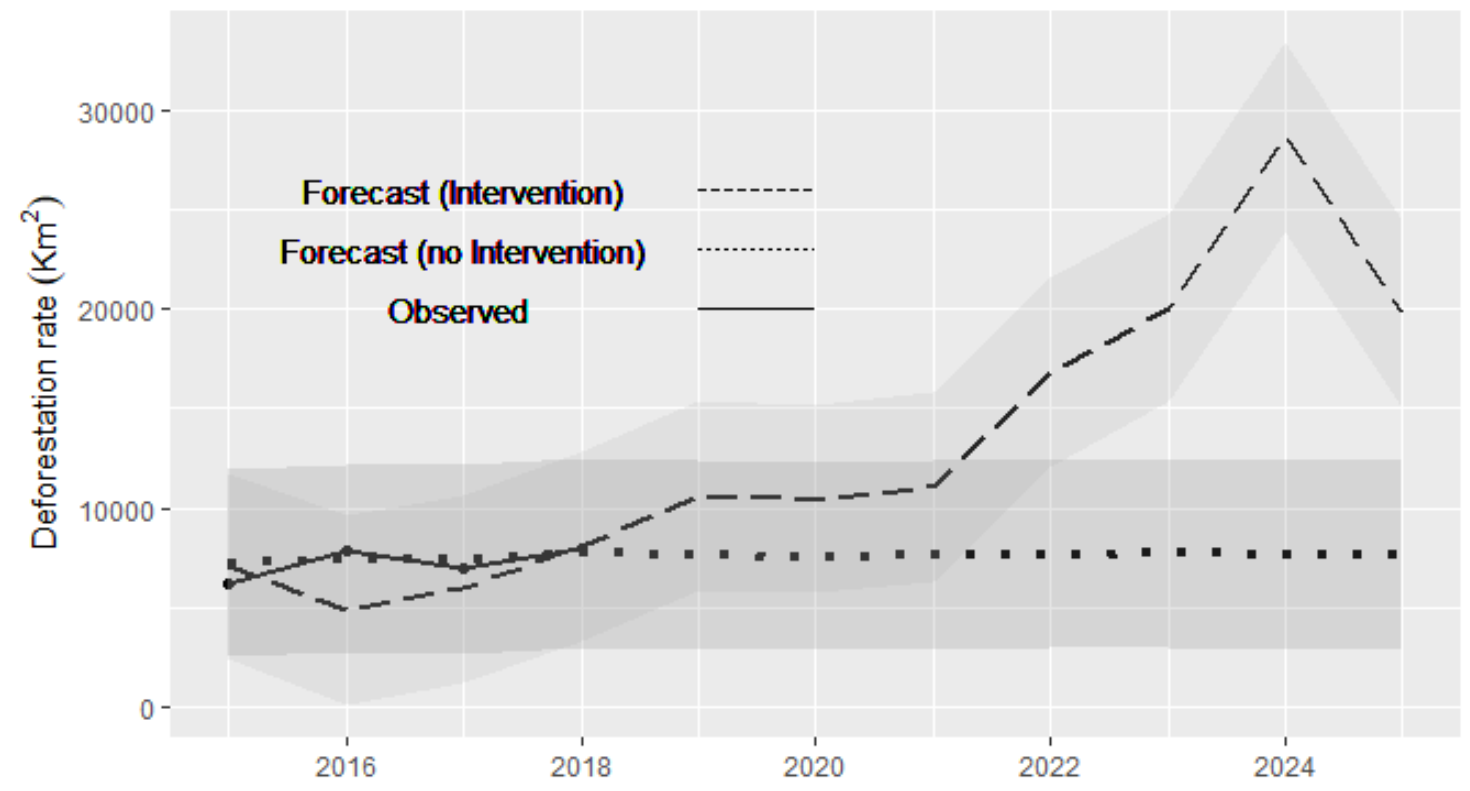

Source: Authors.

In the event of a future intervention, which could be due to changes in the Forestry Code by the Federal Government, where there are several assumptions that such changes could cause increased deforestation (Flavio et al, 2018), forecast estimates should behave differently. It was considered an intervention similar to the one occurred in 2004, given by the impulse-exponential model, shown in Figure $2 \mathrm{c}$ and given in the equation (7). In this more pessimistic scenario, one can have deforestation rates ranging from 10429.28 to $28669.75 \mathrm{~km}^{2}$ and an average of $117366.98 \mathrm{~km}^{2}$, with confidence intervals ranging from 5698.85 to $33408.10 \mathrm{~km}^{2}$. In the period considered from 2019 to 2025 with this scenario, around $117366.98 \mathrm{~km}^{2}$ will be deforested, an increase of about $119.88 \%$ compared to the scenario of absence of any type of intervention (Table 2 and Figure 5). The deforestation rate reported by INPE for 2019, updated on 6/15/2020, was $10219 \mathrm{~km}^{2}$, a value that is in accordance with the forecast model presented in this work (Table 2). 
Table 2. Deforestation rate forecasts $\left(\mathrm{km}^{2}\right)$ in the Amazon.

\begin{tabular}{rrrr|rrr}
\hline \multirow{2}{*}{ YEAR } & \multicolumn{3}{c|}{ Without Intervention } & \multicolumn{3}{c}{ With Intervention } \\
\cline { 2 - 7 } & Prediction & LI(95\%) & LS(95\%) & Prediction & LI(95\%) & LS(95\%) \\
\hline 2019 & 7629.40 & 2898.97 & 12359.83 & 10629.39 & 5898.96 & 15359.8 \\
2020 & 7559.97 & $\mathbf{2 8 2 9 . 5 4}$ & 12290.40 & 10429.28 & $\mathbf{5 6 9 8 . 8 5}$ & 15159.7 \\
2021 & 7602.64 & 2872.21 & 12333.07 & 11062.53 & 6332.11 & 15793 \\
2022 & 7666.26 & 2935.83 & 12396.69 & 16790.13 & 12059.7 & 21520.6 \\
2023 & 7730.88 & 3000.46 & $\mathbf{1 2 4 6 1 . 3 1}$ & 20046.33 & 15315.9 & 24776.8 \\
2024 & 7599.79 & 2861.42 & 12338.16 & 28669.75 & 23931.4 & $\mathbf{3 3 4 0 8 . 1}$ \\
2025 & 7586.88 & 2848.24 & 12325.53 & 19739.57 & 15000.9 & 24478.2 \\
\hline Total & 53375.82 & & & 117366.98 & & \\
\hline Average & 7625.12 & & & 16766.71 & & \\
\hline
\end{tabular}

LI and LS: Confidence Limits of 95\%, Inferior and Superior, respectively.

In bold, minimum and maximum values, respectively.

Source: Authors.

It is worth to mention that, a study produced by Matricardi et al. (2018), in the MATOPIBA region, where the forecasts generated by the time series were presented at intervals of five years until 2050 to facilitate the visualization of the deforestation dynamics in the period of analysis. The results of the simulations predict an increase of $14.1 \%, 21 \%$, and $21.7 \%$ of deforestation by 2050 in the study area, assuming the optimistic, biased and pessimistic scenarios, respectively. Thus, this study region would have a total of $29 \pm 1,17,34,1 \pm 1,75$ and $34,6 \pm 1,8$ million hectares of native vegetation cleared by 2050 in the optimistic, biased and pessimistic scenarios, respectively.

These major changes in forest cover have important implications for biodiversity loss and other ecosystem services, greenhouse gas emissions, in particular $\mathrm{CO}_{2}$, and the long-term prosperity of Amazonian society (Diniz, 2017).

Another study that was also tested by Jian et al. (2011), where the Autoregressive Moving Average Models (Arima) was introduced to increase the predictability of the ecological foot print indicator that is defined as the impact or consequence left by human activity. The study area was in the Chinese province of Henan, data were collected from 1949 to 2006. Based on the calculated results, the ARIMA model simulation process was favorable.

It is visible, the need for more environmental inspection efforts. Firstly, with the increase in the issuance of fines, and should include the embargo on illegal enterprises (eg illegal sawmills or illegal logging).

A study made by Sales \& Souza (2011) well predicted deforestation sites from August 2010 to July 2012. The results of this prediction show that deforestation risk models can be an important tool for deforestation prevention in the Amazon, because they indicate the locations at risk with good accuracy.

\section{Conclusions}

Thus, it is emphasized the importance of continued actions that allow a timely assessment of the evolution of deforestation in the Amazon, that can bring information to guide the development plans and policies in the region, with a view to promoting more sustainable use of the territory.

If there is no significant intervention in the series, deforestation rates are expected to stabilize in the coming years, by 2023. Otherwise, deforestation rates could increase rapidly. 
It should be noted that the results obtained in this research provide an indication of deforestation behavior in the next 7 (seven) years of anticipation. These forecasts are important because they allow preventive measures to reduce these numbers and thus help to reduce the damage caused to the environment.

In this sense, we hope that the forecasts will help in prevention and combating campaigns to prevent future deforestation. The study of forecasts justifies an effort by environmental authorities to ensure the reduction of deforestation through environmental control, enforcement of laws with punishment for violators, land regularization and the creation of Conservation Units.

It is necessary to understand the causes of deforestation in the Brazilian Amazon, in order to make decisions to mitigate impacts on Amazonian ecosystems. In this case, it is suggested that in the next surveys increase the historical series of deforestation, so that the results can contemplate the entire time series of deforestation over the years.

\section{References}

Abdel-Aal, R. E. \& Al-Garni Z. (1997). Forecasting monthly electric energy consumption in eastern Saudi Arabia using univariate time-series analysis. Energy, 22(11), 1059-1069.

Andrade, de S. S., Palmer, C. \& Di Falco, S. (2013). Dynamics of indirect land-use change: empirical evidence from Brazil. Journal of Environmental Economics and Management, 65(3), 377-393.

Aldrich, S. P. (2015). Decision-making and the environment in the Amazon Land War. J. Land Use Sci. 10 (1), 38-58.

Aldrich, S., walker, R., Simmons, C., Caldas, M., \& Perz, S. (2012). Contentious land change in the Amazon's arc of deforestation. Ann. Assoc. Am. Geogr. 102 (1), 103-128.

Alencar, A., Nepstad, D., Mcgrath, D., Moutinho, P., Pacheco, P., Diaz, M. D. C. V. (2004). Desmatamento na Amazônia: indo além da “emergência crônica". Belém, Pa: Instituto de Pesquisa Ambiental da Amazônia - IPAM.

Alix-garcia, J., Arausch, L. L., L’ROE, J., Gibbs, H. K. (2018). Avoid deforestation linked to environmental registration of properties in the brazilian Amazon. Conservation Letters, 11 (3), 1-8.

Almeida, C. A, Valeriano, D. M., Escada, M. I. S., \& Renno, C. D. (2010). Estimation of secondary succession area in the Brazilian Legal Amazon. Acta Amazonica, 40(2), 289-302.

Alves, R. N. B., \& Homma, A. K. O. (2008). Amazônia do Verde ao Cinza. (2a ed.), Embrapa Amazônia Oriental.

Andersen, L. E., Eustaquio, R., Clive, W. J. G., \& Diana, W. (2002). The Dynamics of deforestation and economic growth in the brazilian Amazon. United Kingdom: Cambridge University Press.

Ansley, C., \& Newbold, P. (1980). Finite sample properties of estimators for autoregressive moving average models. Journal of Econometrics, 13(2), 159-183.

Arima, E., Barreto, P., \& Brito, M. (2006). Pecuária na Amazônia: tendências e implicações para a conservação ambiental. Instituto do Homem e Meio Ambiente da Amazônia. Belém, Pa. 〈www.imazon.org.br〉.

Arima, E. Y., Richards, P., Walker, R., \& Caldas, M. (2011). Statistical confirmation of indirect land use change in the Brazilian Amazon. Environmental Research Letters, 6, 1e7.

Alston, L. J., \& Mueller, B. (2010). Property rights, land conflicts and tenancy in Brazil. Cambridge, MA, National Bureau of Economic Research. (NBER Working Paper 15771).

Azevedo-Ramos, C., \& Moutinho, P. (2018). Land Use Policy No Man's Land in the Brazilian Amazon: Could Undesignated Public Forests Slow Amazon Deforestation? Land Use Policy 73, 125-27.

Azevedo, A. A., Rajão R., Costa M. A., Stabille, M. C. C., Macedo, M. N., Reis, T. N. P., Alencar, A., Soares-Filho, B. S \& Pacheco, R. (2017). Limits of Brazil's forest code as means to end illegal deforestation. PNAS, 114(29), 7653-7658.

Barreto, P., Pereira, R., \& Arima, E. B. P. (2008). A Pecuária e o desmatamento na Amazônia na Era das Mudanças Climáticas. (p. 40). Imazon.

Box, G. E. P, \& Jenkins, G M. (1976). Time series analysis forecasting and control. San Francisco: Holden-Day, Edição revisada.

Brasil. Ministério da Saúde. (2007). Ações de ciência, tecnologia e inovação em saúde para a Amazônia Legal. Revista Saúde Pública, 41(1), $158-162$.

Bressan, A. A. (2004). Tomada de decisão em futuros agropecuários com modelos de previsão de séries temporais. RAE-eletrônica, 3(1), 9, <http://www.scielo.br/pdf/raeel /v3n1/v3n1a04.pdf>.

Bressan, A. A., \& Lima, J. E. (2002). Modelos de previsão de preços aplicados aos contratos futuros de boi gordo na BM\&F. Nova Economia, 12(1), 117-140.

Brocklekanb, J. C., Dickey, D. A. (2003). SAS for Forecasting Time Series. (2nd ed.), Cary, NC: SAS Institute. 
Brown, D. S., Brown, J. C., \& Brown, C. (2016). Land occupations and deforestation in the Brazilian Amazon. Land use Policy 54, $331-338$.

Castro, E. (2005). Dinâmica socioeconômica e desmatamento na Amazônia. Novos Cadernos do NAEA. 8(2), 5-39.

Celentano, D., \& Veríssimo, A. (2010). A Amazônia e os objetivos do milênio 2010. Imazon.

Diaz, M. C. V., Kaufmann, R, Nepstad, D, \& Schlesinger, P. (2008). An interdisciplinary model of soybean yield in Amazon Basin: the climatic, edaphic, and economic determinants. Ecological Economics, 65(2), 205-240

Diniz, M. B., et al (2018). Dinâmica de curto prazo do desmatamento da Amazônia Legal: uma análise do papel das políticas públicas entre os anos de 2000 e 2010. Revista de Economia Aplicada. 22(4), 176-206.

Diniz, M. B. (2017). Desmatamento e Ausência de Riqueza na Amazônia. Belém-Pa. Editora Belém-Pa. Paka-Tatu.

Diniz, M. B., Alves, V. Paixão, \& Diniz, M. J. T. (2018). Does Amazonian land use display market failure? An opportunity-cost approach to the analysis of Amazonian environmental services. Cepal Review. 126, 109-129.

Domingues, M. S., \& Bermann, C. O. (2012). Arco do desflorestamento na Amazônia: da pecuária a soja. São Paulo: Ambiente \& Sociedade, 2, 1-22.

Faria, W. R., \& Almeida, A. N. (2016). Relationships between openness to trade and deforestation: empirical evidence from Brazilian Amazon. Ecological Economics 121, 85-97.

Fearnside, P. M. (2005). Desmatamento na Amazônia brasileira: história, índices e conseqüências. Megadiversidade, 1(1).

Fearnside, P. M. (2006). Desmatamento na Amazônia: dinâmica, impactos e controle. Acta Amazônica. 36(3), 395-400.

Ferreira, M. D. P.; \& Coelho, A. B. (2015). Desmatamento Recente nos Estados da Amazônia Legal: uma análise da contribuição dos preços agrícolas e das políticas governamentais. Resr, 55(1), 93-108.

Flavio, L. M. F., Sparovek, G., Berndes, G., Persson, U. M., Englund, O., Barreto, A., \& Mortberg, U. (2018). Potential increase of legal deforestation in Brazilian Amazon after Forest Act Revision. Nature Sustainability 1, 665-670.

Fonseca, J. S., Martins, G. A., \& Toledo, G. S. (1985). Estatística aplicada. (2nd ed.), Atlas, 459p.

Foody, G. M., Palubinskas, G., Lucas, R. M., Curran, P. J., \& Honzak, M. (1996). Identifying terrestrial carbon sinks: classification of successional stages in regenerating tropical forest from Landsat TM data. Remote Sensing of Environment, 55, 205-216.

Geist, H. J., \& Lambin, E. F. (2001). What drives tropical deforestation. A meta-analysis of proximate and underlying causes of deforestation based on subnational case study. Ciaco: Louvain-la-Neuva LUCC Report Series n 4: 2001.

Gibbs, H. K., Rausch, L., Munger, J., Schelly, I., Morton, D. C., Noojipady P., Soares-Filho, B., Barreto, P., Micol, L., \& Walker, N. F. (2015). Brazil’s Soy Moratorium. Science, 347, 377-378.

Gonçalves, C, W. P. (2004). Geografia da riqueza, fome e meio ambiente: pequena contribuição crítica ao atual modelo agrário/agrícola de uso dos recursos naturais. Em: Oliveira, A. U. \& Marques, M. I. M (Org.). O campo no século XXI: território da vida, de luta e de construção da justiça social. São Paulo: Casa Amarela; Paz e Terra, p.27-64.

Hecht, S. B. (2012). The natures of progress: land use dynamics and forest trends in Latin American and the Caribbean. Inter-American Development Bank (Technical Notes $n^{\circ}$ IDB-TN-387)

Herrera, D., Pfaff A., \& Robalino, J. (2019). Impacts of protected areas vary with the level of government: Comparing avoided deforestation across agencies in the Brazilian Amazon. PNAS, 116(30), 14916-14925.

Inpe (Instituto Nacional de Pesquisas Espaciais). Prodes (Projeto de Estimativa de Desflorestamento da Amazônia): São José dos Campos- INPE, $\leq$ http://www.obt.inpe.br/OBT/assuntos/programas/amazonia/prodes/ $\geq$.

Instituto Brasileiro De Geografia E Estatística (IBGE). (2010). Áreas especiais: Amazônia Legal. http://www.ibge.gov.br/home/geociencias/ geografia/amazonialegal.shtm>

Ian J-S, et al (1993). An Introduction to the Bootstrap. Tibshirani. London, Chapaman and Hall.

Jaramillo, C. F., \& Thomas, K. (1997). Deforestation and property rights in Latin America. Inter-American Developed Bank.

Kahn, J. R. (2005). The economic approach to environmental economics. (3a ed.), Thomson; South Western, USA.

Kaimovitz, D., \& Angelsen A. (1998). Economic models of tropical deforestation. A review. Bogor, Indonesia: Center for International Forestry Research.

Lucas, R. M., Honzak, M., Amaral. I., Curran, P. J., \& Foody, G. M. (2002). Forest regeneration on abandoned clearances in central Amazonia. International. Journal of Remote Sensing, 23(5), 965-988.

Marengo, J A., Liebmann, B., Kousky, V. E., Filizola, N. P., \& Wainer, I. C. (2001). Onset and end of the rainy reason in the Brazilian Amazon basin. Journal of Climate, 14, 833-852.

Margulis, S. (2003). Causas do desmatamento da Amazônia Brasileira. Banco Mundial. 
Matricardi, E. A. T., Aguiar, A. S., Miguel, E. P., Angelo, H., \& Gaspar, R. O. (2018). Modelagem do desmatamento na região do MATOPIBA. Nativa, Sinop, v. 6, n. 2, p. 198-206.

Morettin, P. A., \& Toloi, C. M. C. (2004). Análise de séries temporais. Edgard Blücher.

Moura, A. M. M. (2016). Governança Ambiental no Brasil: institucionais, atores e políticas públicas. Brasília, DF: Ipea.

Mueller, C. C., \& Bustamante M. (2002). Análise da expansão da soja no Brasil. s/l. <www.worldbank.org/rfpp/news/debates/mueller.pdf>.

Nepstad, D. C., et al. (2001). Road paving, fire regime feedbacks, and the future of Amazon forests. Forest Ecology and Management, 154, 395-407.

Nepstad, D. C., Stickler, C., \& Almeida O. T. (2008). A globalização das indústrias de soja e de gado na Amazônia: oportunidades para a conservação. In: Sérgio Rivero; Frederico G. Jayme Jr. (orgs). As Amazônias do Século XXI. Belém, Pa: Ed. da Universidade Federal do Pará. pp. 41 -66.

Nepstad, D., Mcgrath, D., Stickler, C., Alencar, A., Azevedo, A., Swette, B., Bezerra, T., Digiano, M., Shimada, J., Seroa, da Motta R., Armijo, E., Castello, L., Brando, P., Hansen, M. C., Mcgrath-Horn, M., Carvalho, O., \& Hess, L. (2014). Slowing Amazon Deforestation Through Public Policy and Interventions in Beef and Soy Supply Chains. Science vol. 344 June.

Pearce, D. W., \& Brown K. (1994). Saving the world's tropical forest. In: Brown K, Pearce D W. (Eds.). The causes of tropical deforestation: the economic and statistical analysis of fator giving rise to the loss of tropical forests. London: University College Press; Vancouver: University of British Columbia Press, p.226.

Pearce, D. W. (1998). Economics and environment. Essays on Ecological Economis and Sustainable Development. Northampton, MA, USA: Edward Elgar.

Pfaff, A., Barbieri, A., Ludewigs, T., Merry, F., Perz, S., \& Reis, E. (2009). Impactos de estradas na Amazônia brasileira. Amazonia and Global Change. Geophysical Monograph Serie 186. American Geophysical Union, 2009.

Richards, P., Walker, R., \& Arima, E., (2014). Spatially Complex Land Change: The Indirect Effect of Brazil's Agricultural Sector on Land Use in Amazonia. Global Environmental Change, 29, p.1-9.

Rausch, L. I., \& Gibbs, H. K. (2016). Property Arrangements and Soy Governance in the Brazilian State of Mato Grosso: Implications for Deforestation-Free Production. Land. 5(7), 1-16.

Reydon, B. P. (2011). O Desmatamento da floresta amazônica: causas e soluções. Economia Verde: Desafios e Oportunidades (8):143-55.

Reydon, B. P., Fernandes, V. B., \& Telles, T. S. (2020). Land Use Policy, 94, 1-13. https://doi.org/10.1016/j.landusepol.2019.104313

Rivas, A. (org.). (2014). Economia e valoração de serviços ambientais utilizando técnicas de preferências declaradas. Manaus: EDUA.

Sales, M., \& Souza, JR. C. (2011). Risco de desmatamento. Avaliação de resultados de agosto de 2010 a julho de 2011. Boletim de Avaliação. Imazon. https://imazon.org.br/PDFimazon/Portugues/risco\%20de\%20desmatamento/RD_Avaliacao_Ago10_Jul11.pdf.

Scrieciu, S. S. (2007). Can economic causes of tropical deforestation be identified at global level? Ecological Economics 62, 603-612.

Simmons, C. S., Walker, R., Perz, S., Aldrich, S., Caldas, M., Pereira, R., Fernandes, C., \& Arima, E., (2010). Doing it for themselves: direct action land reform in the Brazilian Amazon. World Dev. 38 (3), 429-444

Soares-Filho, B. S., Nepstad, D. C., Curran, L., Cerqueira, G. C., Garcia, R. A., Ramos, C. A., Voll, E., Mcdonald, A., Lefebvre, P., Schlesinger, P., Mcgrath, D. (2005). Cenários de Desmatamento Para a Amazônia. Estudos Avançados 19 (54):137-52.

Soares-Filho, B. S., Rajão, R., Macedo, M., Carneiro, A., Costa, W., COE, M., Rodrigues, H., \& Alencar, A. (2014). Cracking Brazil's Forest Code. Science 344 (6182): 363 LP-364.

Soares-Filho, B. S., Moutinho, P., Nepstad, D. C., Anderson, A., Rodrigues, H., Garcia, R., Dietzsch, L., Merry, F., Bowman, M., Hissa, L., Silvestrini, R., Maretti, C. (2010). Role of Brazilian Amazon Protected Areas in Climate Change Mitigation. PNAS 107 (24):10821-26.

Souza, E. B., \& Ambrizzi T. (2003). Pentad precipitation climatology over Brazil and the associated atmospheric mechanisms. Climanálise, 1,1-20. <www.cptec.inpe.br/products/climanalise/artigos/artcien2.shtml>.

Tucci, C. E. M., (1998). Modelos hidrológicos. Ed. da UFRGS/ABRH. 669p.

Ustin, S. L., Smith, M. O., Jacquemoud, S., Verstraete, M., Govaerts, Y. (1999). Geobotany: Vegetation Mapping for Earth Sciences. In Remote Sensing for the Earth Sciences - Manual of Remote Sensing. A. N. Rencz. (3rd ed.) 3. John Wiley \& Sons, 189-249.

Walker, N., Patel, S., Davies, F., Milledge, S., Hulse, J. (2013). Demand-Side Interventions to Reduce Deforestation and Forest Degradation The International Institute for Environment and Development - IIED; The Global Canopy Programme - GCP; CDP Forests; The Price's Rainforest Project. London, UK (January 2013):27.

Walker, R. T. (1987). Land use transition and deforestation in developing countries. Geographical Analysis, 19(1), Ohio State University Press.

Walker, R., Moran, E., \& Anselin, L. (2000). Deforestation and cattle ranching in the Brazilian Amazon: external capital and household process. World Development. 28(4), 683-699.

Walker, R. T. (2003). Mapping process to pattern in the landscape change of the Amazonian Frontier, Ann. Assoc. Am. Geogr., 93(2).

Walker, R., Defries, R., Vera-Diaz, M. D. C., Shimabukuro, Y., \& Venturieri, A. (2009). A expansão da agricultura intensiva e pecuária na Amazônia brasileira. In Michael Keller et al. (editors). Amazonia and Global Change. American Geophysical Union, Washington, D.C. Geophysical Monograph Series 186. 
Research, Society and Development, v. 10, n. 4, e8710413787, 2021

(CC BY 4.0) | ISSN 2525-3409 | DOI: http://dx.doi.org/10.33448/rsd-v10i4.13787

Walker, W., Baccini, A., Schwartzman, S., Ríos, S., Oliveira-Miranda, M. A., Augusto, C., Ruiz, M. R., Arrasco, C. S., Ricardo, B., Smith, R., Meyer, C., Jintiach, J. C., \& Campos, E. V. (2014). Forest carbon in Amazonia: the unrecognized contribution of indigenous territories and protected natural areas, Carbon Management, 5:5-6, 479-485,

Wei, W. S. (1989). Time series analysis: univariate and multivariate. Addison-Wesley.

Wehkamp, J. et al. (2018). Governance and deforestation — a meta-analysis in economics. Ecological Economics, 144, 214-227.

Werner, L., Ribeiro, J. L. D. 2003. Previsão de Demanda: Uma Aplicação dos Modelos Box-Jenkins na área de assistência técnica de computadores pessoais. Gestão \& Produção, 10(1), 47-67.

Wehmann, M. E. S., \& Duarte, L. M. G. (2004). O que há em comum entre a região das missões e lavrados de Roraima? ou os percursos da soja até a Amazônia Legal. Em: Amazônia cenas e cenários. Brasilia. Ed. Da Universidade de Brasília.

WWF. (2014). The Growth of soy: impacts and solutions. WWF International. Gland Switzerland. 